Section Editor

Mitchell S.V. Elkind, MD, MS

\title{
Teaching NeuroImages: \\ Glutaric aciduria type 1 (glutaryl-CoA dehydrogenase deficiency)
}

Paramdeep Singh, MD Jatinder Singh Goraya, $\mathrm{MD}$

Archana Ahluwalia, MD

Kavita Saggar, MD

Address correspondence and reprint requests to Dr. Paramdeep Singh, Department of Radiology,

Dayanand Medical College \& Hospital (DMCH), Ludhiana (Punjab), India paramdeepdoctor@gmail.com

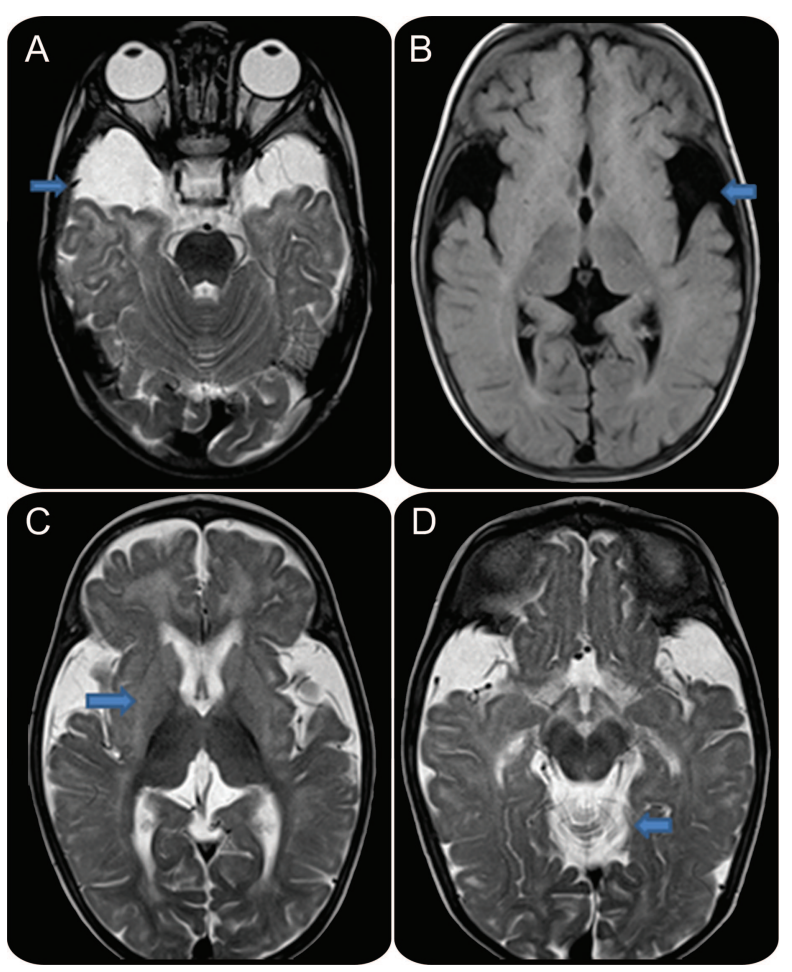

(A) T2-weighted image showing hypoplasia of bilateral temporal lobes with enlarged subarachnoid spaces (arrow). (B) Fluidattenuated inversion recovery image demonstrating squared appearance (arrow) of enlarged sylvian fissures due to underoperculization. (C) T2-weighted image showing hyperintense basal ganglia (arrow), deep and subcortical white matter. (D) T2-weighted image showing widened mesencephalic cistern (arrow).

A 14-month-old boy presented with loss of developmental milestones and tonic spasms following a diarrheal illness. He was born to nonconsanguineous parents and had mild motor delays. Examination was remarkable for macrocephaly, axial hypotonia, and asymmetric dystonic posturing of neck, trunk, and extremities. Brain MRI (figure) and elevated glutaryl carnitine on tandem mass spectroscopy were diagnostic of glutaric aciduria type 1 (GA-1). ${ }^{1}$

Widening of the sylvian fissures, mesencephalic cistern, and enlarged pretemporal subarachnoid spaces are cardinal MRI features. ${ }^{2}$ GA-1 should be considered in any infant or young child with acute encephalopathy in the presence of macrocephaly and extrapyramidal manifestations.

\section{AUTHOR CONTRIBUTIONS}

Dr. Singh participated in acquisition of data and drafting/revising the manuscript. Dr. Goraya participated in acquisition of data, study concept or design, analysis or interpretation of data, and drafting/revising the manuscript. Dr. Ahluwalia participated in analysis or interpretation of data and study supervision. Dr. Saggar participated in analysis or interpretation of data and study supervision.

\section{REFERENCES}

1. Neumaier-Probst E, Harting I, Seitz A, et al. Neuroradiological findings in glutaric aciduria type I (glutaryl-CoA dehydrogenase deficiency). J Inherit Metab Dis 2004;27: 869-876.

2. Twomey EL, Naughten ER, Donoghue VB, et al. Neuroimaging findings in glutaric aciduria type 1. Pediatr Radiol 2003;33:823-830. 


\section{Neurology}

\section{Teaching NeuroImages: Glutaric aciduria type 1 (glutaryl-CoA dehydrogenase deficiency)}

Paramdeep Singh, Jatinder Singh Goraya, Archana Ahluwalia, et al. Neurology 2011;77; 6

DOI 10.1212/WNL.0b013e31822313f6

\section{This information is current as of July 4, 2011}

\section{Updated Information \& Services}

References

Citations

Subspecialty Collections

Permissions \& Licensing

Reprints including high resolution figures, can be found at: http://n.neurology.org/content/77/1/e6.full

This article cites 2 articles, 0 of which you can access for free at: http://n.neurology.org/content/77/1/e6.full\#ref-list-1

This article has been cited by 1 HighWire-hosted articles: http://n.neurology.org/content/77/1/e6.full\#\#otherarticles

This article, along with others on similar topics, appears in the following collection(s):

All Pediatric

http://n.neurology.org/cgi/collection/all_pediatric

Metabolic disease (inherited)

http://n.neurology.org/cgi/collection/metabolic_disease_inherited MRI

http://n.neurology.org/cgi/collection/mri

Information about reproducing this article in parts (figures,tables) or in its entirety can be found online at:

http://www.neurology.org/about/about_the_journal\#permissions

Information about ordering reprints can be found online: http://n.neurology.org/subscribers/advertise

Neurology ${ }^{\circledR}$ is the official journal of the American Academy of Neurology. Published continuously since 1951, it is now a weekly with 48 issues per year. Copyright Copyright () 2011 by AAN Enterprises, Inc.. All rights reserved. Print ISSN: 0028-3878. Online ISSN: 1526-632X.

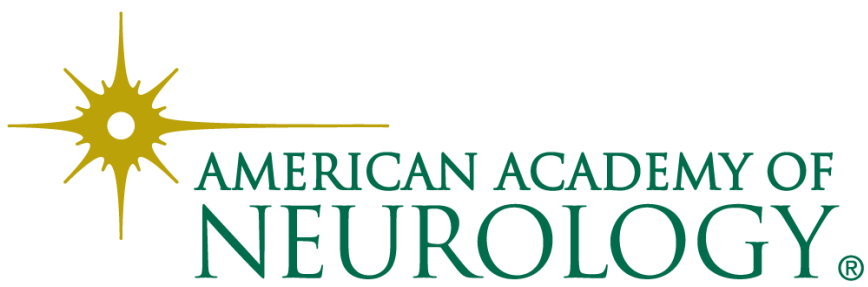

